\title{
Military Operations, Law and Late Imperial Space: The Spread of Militarized Adjudication
}

Opérations militaires, droit et espace dans l'empire tardif : l'essor des procédures judiciaires militarisées

軍法與常法: 刑事裁判中的時空作用

\section{E. John Gregory}

\section{OpenEdition}

\section{Journals}

Electronic version

URL: http://journals.openedition.org/extremeorient/601

DOI: 10.4000/extremeorient.601

ISBN: 978-2-84292-558-1

ISSN: 2108-7105

Publisher

Presses universitaires de Vincennes

Printed version

Date of publication: 21 November 2016

Number of pages: $59-78$

ISBN: 978-2-84292-556-7

ISSN: 0754-5010

\section{Electronic reference}

E. John Gregory, « Military Operations, Law and Late Imperial Space: The Spread of Militarized Adjudication », Extrême-Orient Extrême-Occident [Online], 40 | 2016, Online since 21 November 2018 connection on 25 April 2019. URL : http://journals.openedition.org/extremeorient/601 : DOI : 10.4000/ extremeorient.601 


\title{
Military Operations, Law and Late Imperial Space: The Spread of Militarized Adjudication
}

\author{
E. John Gregory
}

The scholarly community has written extensively on how criminal cases were adjudicated during the late Ming (1368-1644) and Qing (16441912) dynasties. ${ }^{1}$ By the mid-Qing, the system consisted of multiple levels of hierarchical retrial-review up to the central government and mandatory review and approval by the emperor of certain cases, including most cases involving death sentences. This routine adjudicative process was a deliberate and time-consuming process that was usually the norm for criminal cases that were adjudicated within the inner empire (neidi) during times of peace. At the same time, scholars have long recognized that the Qing sometimes applied different law to different peoples across its multi-ethnic empire. ${ }^{2}$ What this scholarship on the sophistication of Qing criminal process and application of diverse Qing law has missed, however, is that there also existed throughout the Ming and Qing eras a far more simplified form of criminal adjudication that was also applied largely as a function of space. This simplified form of adjudication was closely, although not exclusively, associated with military cases and is probably best called by its most generic appellation, "militarized adjudication" (Ch: yi junfa congshi; Manchu: coohai fafun i gamarangge), a term that appears frequently in Ming-Qing archives.

During the Ming and Qing eras, the most simplified form of militarized adjudication-summary execution of an alleged offender by an official operating in the field with only post hoc notice to the imperial center and little to no review-was alternatively referred to in popular speech as "executing first and memorializing later" (xianzhan houzou), or executing under the

1. This system was described in detail as early as the 1960's in Bodde and Morris 1973; a more recent work describing the procedural system in detail is Chang 1994.

2. Heuschert 1998: 310-24; Farquhar 1968. 


\section{E. John Gregory}

authority of the imperial sword (shangfang baojian) or battle axe (fuyue). ${ }^{3}$ These latter terms are almost entirely absent from the Qing official discourse, save very sporadic references in memorials, the Veritable Records, and the Collected Statutes, however the practice of militarized execution continued and actually expanded during the Qianlong era (r. 1735-96) under a new discourse of delegated imperial authority referred to as immediately executing under authority of the imperial standard (gongqing wangming jixing zhengfa).

Within the historical record, it is easy to distinguish criminal cases adjudicated under the routine process from those handled by way of militarized adjudication. As linguistic, symbolic, and practical discourse, militarized adjudication was composed of a recognizable analytical approach and included distinct symbols with meanings that varied over time. Such cases often cited campaign orders (junling; haoling; faling). ${ }^{4}$ Rather than reflecting the action of multiple hierarchical offices and central government agencies involved in the routine retrial-review process, the adjudicative discourse in militarized adjudicationwas often limited to communications between a highlevel official in the field (e.g., qinchai dachen, jinglüe, governor, governorgeneral) charged with military duties and the emperor (or the imperial office). Sometimes this communication consisted of nothing more than a post hoc and summary notification from the official that he had autonomously executed an offender. Whereas it was common for an early Qing routine criminal memorial documenting the routine process (xingke tiben) to be more than forty folds in length, a militarized adjudication memorial was commonly less than eight folds in length (sometimes just three or four folds). Towards the end of the Kangxi reign (r. 1662-1722), militarized adjudication matters could be entirely selfcontained within one or two palace memorials (zhupi zouzhe) whereas death penalty cases processed under routine adjudication still generated extensive xingke tiben at the central-government level.

As the name suggests, militarized adjudication was a concept associated with military law (junfa; M: coohai fafun). "Military Law," already known in the time of the Qin and Han dynasties (206 BC-AD 220), did not develop as an exception to the civilian law, but in many ways preceded it. ${ }^{5}$ The concept was well developed by the Ming dynasty. ${ }^{6}$ In fact, traditional Chinese

3. Zhang 2012: 571 .

4. A number of these campaign orders can be found in the "campaign" section of the Collected Statutes (precedents) (1749).

5. Zhou and Jia 1999: 38-40. See also Zhou 2008.

6. The term junfa appeared in many literary references starting around the Qin dynasty (221-206 BC). Sima Guang's eleventh-century Song classic A Comprehensive Mirror 
historiography holds that "punishment started with the military (xing shiyu bing)." $"$ By at least the mid-Ming, the Chinese term junfa had two broad meanings. First, it referred to militarized adjudication, a particular mode of trying cases; second, it referred to the entire body of laws that represented the proper legal-norms of military behavior, what one might cautiously call a form of substantive law. This military law included a vast array of rules and laws from temporary campaign orders (junling) to administrative provisions (such as those contained in the late seventeenth and eighteenth-century Central Military Administrative Reference (Zhongshu zhengkao) and later in the early nineteenth-century Administrative Sanctions of the Board of Punishments (Bingbu chufen zeli). ${ }^{8}$ The Military Law (Binglii) section of the Ming-Qing Codes (the Daqing luli and its predecessor codes) also set forth military law. Militarized adjudication, however, and (substantive) military law were not always co-extent.

By the time of the Ming, when a soldier or military-related official violated military law, it did not necessarily follow that he would be tried under the simplified procedures of militarized adjudication. In fact, most of the crimes defined under the Military Law section of the Code were structurally indistinguishable from other crimes in the Ming-Qing criminal Codes and, despite the fact that these crimes were "military crimes," they were generally intended to be adjudicated under the drawn-out retrial-review process, similar to non-military crimes defined in the Code. Even when institutionalmilitary cases were tried under special military-related offices and officials, at least during peacetime, the overall process (trial, retrial, and approval by the emperor, if applicable) was generally similar to non-military cases. ${ }^{9}$ This raises the question, under what circumstances were military cases tried by way of militarized adjudication? In this essay, I demonstrate that thinking of these cases spatially - thinking of the method of adjudication loosely as a function of where the underlying crime occurred and/or where the suspect was located at the time of trial-helps us understand why some military cases were tried under militarized adjudication and some were not. This, in turn helps us understand why the frontier increasingly came to be seen as a zone of legal significance during the Qing. Finally, it helps us understand why militarized adjudication expanded significantly with the significant increase in military

for Government (Zizhi tongjian) contained many references to junfa from previous dynasties, reflecting both militarized adjudication and other meanings.

7. Zhu 2010: 67-81; Zeng 2011: 40-42.

8. Zhongshu zhengkao (1742).

9. Zhou 2008: 304. 


\section{E. John Gregory}

activity associated with the Qianlong emperor's (r. 1735-96) vast expansion of imperial space.

\section{Spatial Influence on the Development of Militarized Adjudication}

The Seven Military Classics, originating mostly during the Warring States period (403-221 BC), early on recognized that rules of military discipline had to be clear, and punishment had to be quick in order to maintain the authority of the commander and unit discipline during battle. ${ }^{10}$ They already contained the basic ideas of awards and punishments (shangfa) and emphasized that expeditiousness and lack of leniency were critical to military discipline. By the mid-Ming, the association between militarized adjudication and battlefield operations was well-recognized. For instance, Neo-Confucian philosopher and fifteenth-century Board of War minister Wang Yangming (1472-1529) authored a number of memorials while a secretary on the Nanjing Board of War, several of which addressed militarized adjudication, including the following from 1499 discussing actions at the epicenter of military operations:

From now on, for any officer leading soldiers in combat, if soldiers under his command retreat or fail to follow orders, permission is granted to adjudicate the matter in front of the troops according to militarized adjudication (yi junfa congshi). If the leader himself does not follow orders, then the commander-general (zongtong guan) is granted permission to adjudicate the leader's case according to militarized adjudication in front of the troops. ${ }^{11}$

Reaffirming the link between actual battlefield operations and militarized adjudication, in his New Book on Military Discipline (Jixian xinshu), Qi Jiguang (1528-88) described a number of orders listing offenses that were

10. The Seven Military Classics, consisted of works written between the Warring States period and the Song, and were compiled as a cannon during the Song. With some exceptions, they served as a basis for the imperial military examinations during the Qing period. They consisted of: Tai Gong's Six Secret Teaching, Sima Fa, Sunzi's Art of War, Wuzi, Wei Liaozi, The Three Strategies of Huangshi Gong, and Questions and Replies Between Tang Taizong and Li Wei Gong. Sawyer 1993.

11. In July 1517, the Board of War had been requested to grant militarized adjudication authority to the provincial military commander whereas in that particular theater of operations, it had only previously been granted to the grand coordinator. Wang 2011: 32: $39 \mathrm{v}$. 
to be adjudicated according to militarized adjudication while on campaign. ${ }^{12}$ Notably, battlefield retreat was the only offense listed which included completely autonomous authority to carry out the death penalty. ${ }^{13}$ In this regard, Qi Jiguang's work merely reflected long-standing Ming reality that treated fleeing the battlefield as requiring militarized adjudication and permitting full autonomy in carrying out the sentence. ${ }^{14}$ Conceptually, this reflects that militarized adjudication was conceptually situated squarely within the Chinese tradition of granting autonomy to the campaign commander, referred to as "convenience of action (bianyi xingshi)," because it enabled campaign commanders to autonomously adjudicate cases with minimum recourse to the administrative hierarchy. ${ }^{15}$

Since military campaigns often took place on the far frontier, sending a case back to the capital for review by the emperor after multiple levels of review detracted from the required efficiency in administering punishment and detracted from military discipline. In fact, one of the earliest (and only) examples of a military law explicitly calling for militarized adjudication in the Ming-Qing Codes involved military crimes on the frontier. That statute was entitled "execution of military rebels" (chujue panjun). ${ }^{16}$ For this type of military rebellion on the frontier - note both the military subject matter and the association with the frontier-the Ming-Qing Codes permitted local officials to execute an accused following only review by the governor (xunfu) and/or governor-general (zongdu), two officials located at the provincial level, rather than go through the routine process of extended retrial-review and approval by

12. Not maintaining proper order in the ranks during march, leaving the unit without authorization, not obeying the signal drums and signal flags, not abiding or properly transmitting orders, getting lost on the road, and rioting were all to be adjudicated under militarized adjudication ( ju zhi junfa).

13. This provision included the provisions for group punishment, going all the way up the chain of command, making both community heads (jiazhang) responsible as well as ten-men unit leaders (duizhang). If they retreated with their soldiers they were executed. Qi 2012 [1560]: 41-5.

14. The Collected Statutes of the Ming (Daming Huidian) already included an order from 1449 requiring that if the leader (toumu) was the first to retreat in cowardice, then the justice official was to decapitate him and choose another leader to replace him. If the soldiers regardless of the leader, retreated "first in cowardice on their own," then the soldiers in the ranks behind them were permitted to kill them, and they were to be rewarded for this action. MHD, 111: 6r; QHDSL, 111: 14v-15v.

15. Zhao 2012: 160-61.

16. Qing Code, art. 33. The Qing Code article numbering system used in this essay references Jones 1994. 


\section{E. John Gregory}

the emperor. ${ }^{17}$ Further, if the plotting occurred during battle, then local officials could execute the accused on the spot without even seeking approval from the governor/governor-general. In both cases, the emperor had to be notified immediately after the fact. ${ }^{18}$

While frontier military rebellion statutorily called for militarized adjudication, most instances of militarized adjudication were the result of one time grants of authority based on specific situations. For instance, in an August 7, 1640 (CZ 13/6/20) draft memorial, the Ming Board of War responded to an edict from the Chongzhen emperor seeking recommendations following a disastrous Manchu raid the year prior. The Board styled their memorial a "recommendation that junfa be made manifest (shenming junfa)." But what exactly did the memorialist mean by junfa? We know because he provided a historical example of how such an approach could address discipline problems, noting that in the time of the Ming founder, if soldiers were deployed to battle, yet were incompetent and returned from battle, they were immediately beheaded; likewise, if they stole anything that belonged to the people, they were beheaded. From this, we can surmise that the memorialist was requesting the emperor to authorize officials to carry out highly autonomous death sentences in order to maintain military discipline. At the very end of the memorial, using the same language as in the initial styling of the memorial (shenming junfa), the original drafter requested the emperor to order all governorsgeneral, governors, regional commanders (zongbing), and circuit intendants to make junfa manifest. At some point in the drafting process, the author or another official crossed out that line, and inserted an interlinear correction, requesting "special promulgation of rules to make the criminal process faster and simpler" (teban suxing jieqiu zhi fa). This phrasing really captures the sense of a military process of adjudication; it is not just the substantive law itself, but the manner in which a case was to be adjudicated under the law. ${ }^{19}$ This memorial also reflects the sense of militarized adjudication as something contingent and available only under unique circumstances and authorized to certain officials.

17. Although the terms xunfu and zongdu were used during both the Ming and Qing Codes, the $x u n f u$ and zongdu positions evolved over time. I translate the terms throughout this essay respectively as governor and governor-general for consistency, but agree with Guy Kent that these terms are probably not the best appellation for the positions during the Ming period. Guy 2010.

18. Art. 33. Jones 1994: 67.

19. NGDK, 035347 (CZ 13/6/20). 
By the period of the Ming-Qing transition, militarized adjudication had developed certain relatively fixed characteristics. While both the routine criminal track and militarized adjudication were individual criminal approaches-they saw individual norm-violating behavior as criminal $(z u i)$-the distinction between the two manners of adjudication went beyond the Chinese tradition of "adjusting the harshness of criminal penalties based on the necessities of the times" (shiqing shizhong). The two were distinct modes of adjudication, both constructing the criminal activity in different ways and reflecting distinct criminological viewpoints..$^{20}$ In a general sense, while the routine adjudicative process supported the maintenance of the current political order through the proper performance of judicial procedure and placed a heavy emphasis on providing an offender the opportunity to "renew himself" (zixin), militarized adjudication focused on deterrence, expeditiousness and convenience directed towards maintaining "military discipline" (junji). One of the most significant differences between the two was that militarized adjudication demonstrated none of the structural tendencies towards leniency so obviously present in the routine process, thus lacking were the many opportunities for review in the routine process that often resulted in reduction of sentence or pardon. Due to the close tie between imperial power and reservation of death-penalty approval to the emperor himself, it is not surprising that the greatest extent of autonomous jurisdiction under militarized adjudication was also the rarest: complete autonomy to investigate, try, and carry out death sentences with no retrial-review and only post hoc notification to the emperor. Restrictive grants - far more common-dispensed with various levels of retrial-review but, consistent with the emperor's position at the apex of the criminal-judicial hierarchy, still required final imperial permission prior to carrying out a death sentence.

A 1637 draft memorial from the Ming Board of War demonstrated three things: first, the conceptual link between military discipline and militarized adjudication was deterrence; second, that militarized adjudication was about expedited procedures and judicial autonomy at a level below the emperor; and third, that such authority was always contingent and normally a function of proximity to battle or physical space associated with military activity. In the 1630's, one important epicenter of military operations was the northeast in today's Liaoning and Jilin provinces. By January 1637 (CZ 9/12), with increasing Manchu raids, the Ming Board of War, in conjunction with various governors-general, memorialized the emperor requesting that militarized adjudication authority be granted to the provincial military commissioners

20. Long 2014: 291-92. 


\section{E. John Gregory}

(dufu) extending authority to execute all officials who dithered, retreated or withdrew in the face of barbarian incursions. In response, the Chongzhen emperor (r. 1627-1644) issued an edict authorizing limited militarized adjudication authority to the governors-general and governors of the nine frontiers. His response evinced an awareness of the distinction between militarized adjudication and routine criminal approaches: "for those who should be impeached and then punished, immediately memorialize with an impeachment; for those who should be immediately executed, immediately execute them." ${ }^{21}$ The fact that the governors-general had to specially request militarized adjudication authority as late as 1637 for operations essentially at the epicenter at a life-and-death moment for the dynasty, and that the emperor still limited jurisdiction to cases of accused officials under the rank of colonel provides some idea of the irregular status of militarized adjudication.

From these sources, we get an idea of the relationship between spatial conditions and militarized adjudication.Across the late Ming and post-conquest, early Qing, whether a given military case was adjudicated under the routine process or under militarized adjudication corresponded closely with where the case occurred along what I call the "gradient of military operations." 22 One can think of the epicenter of such a gradient as a particular battlefield (a spatial element) at the time of battle (a temporal element). These two elements were themselves both functions of the intensity of military operations at a given place. Expanding out from this epicenter, multiple and irregularly-shaped zones corresponded with a decreasing intensity of military operations. The innermost zone - where the immediacy of operations made discipline a more poignant concern-was the point at which militarized adjudication was most often invoked. Because the power to approve death sentences was a fundamental prerogative of the emperor's authority, wholly autonomous authority to try and summarily-execute offenders - the fullest extent of militarized adjudication authority - was seldom granted even on campaign except for conduct that occurred at the very epicenter of the gradient.

21. Whenever the rebel Barbarians (zeiyi) breach the frontiers (rukou), governors-general are hereby authorized to "immediately exercise militarized adjudication" (lizheng junfa) to adjudicate cases of officials [in charge of the breached security points] who demonstrated "cowardice" (qie). This authority does not extent to cases of zongbing, circuit intendants (dao), and colonels (fujiang) who must still be impeached and investigated. NGDK, 201343-001 (1/17/1637). For a discussion of the Ming Nine Frontiers System, see Zhao 2012.

22. This concept is more fully developed in my recently-completed dissertation upon which this essay is based (Gregory 2015). 
The outermost zone was an area of either no active military operations or rear-area logistical operations (e.g., the inner empire during times of peace) in which the routine adjudicative process was usually dominant, but not necessarily exclusive. Between the outer zones and the battlefield-epicenter were zones of logistical activity supporting battlefield operations as well as low-intensity military operations, such as routine area defense or various escorting and guard missions. The "deployed camps" (junying; M: coohai $k \bar{u}$ waran) that directly supported military operations were usually located in these inner zones. For criminal adjudication, these inner zones were a gray area where either the routine or adjudicative process or militarized adjudication might pertain.

After the Qing initially occupied Beijing, one can imagine that, with ongoing military operations, most of the north could be classified as falling within the inner zones of the military operations gradient. ${ }^{23}$ Under these circumstances, we can understand how the Qing initially used militarized adjudication to enforce public order. In 1644 (SZ 1), when the epicenter of military operations lay around Shaanxi-Shandong-Henan, Prince of the Blood Dodo (1614-1649) was directed to apprehend former Ming Board of War official Zhang Jinyan and punish him under militarized adjudication. ${ }^{24}$ As the epicenter shifted south after the fall of Yangzhou in 1645, the imperial order went out for Han men to shave the front of their heads and braid their hair in the Manchu style, and it ostensibly subjected violators to militarized adjudication (the actual cases suggest execution authority was still retained by the prince-regent). ${ }^{25}$

The locus of militarized adjudication shifted with movement of the military operations gradient. In 1656, the Zhejiang-Jiangnan border became a significant focus of military operations as part of a coordinated effort between remnants of the Southern Ming and Zheng Chenggong's "loyalist" forces on Taiwan, followed by a major Zheng attack on the mainland in $1659 .{ }^{26}$ Within the context of this shifting epicenter, the Shunzhi emperor issued an edict that any soldiers and officials assigned to low level geographical commands would be immediately punished under militarized adjudication if Zheng's ships made landfall along the eastern coast. ${ }^{27} \mathrm{Here}$, it is clear that the emperor was

23. Adding a layer of complexity, during the Ming-Qing transition, the Qing's pre-conquest evolving military law practices were being adjusted to meet the needs of post-conquest governance.

24. QSL-SZ, 11: 105b

25. QSL-SZ, 17; 150a.

26. Wakeman 1985: 1042-1049.

27. QSL-SZ, 102: 789b. 


\section{E. John Gregory}

using the threat of militarized adjudication as a way to shape future behavior rather than as a tool to adjudicate behavior that had already occurred, a common rhetorical function of junfa. But, it was still the notion of militarized adjudication as expedient and lacking the possibility of leniency that rendered the threat poignant.

Cases from the Yongzheng era (1723-1735) also confirm the relationship between militarized adjudication and the military operations gradient. In a pronouncement relating to soldiers returning from the Zunghar campaigns in 1733, the Yongzheng emperor articulated two different degrees of militarized adjudication for two different positions along the military operations gradient. If someone spread rumors at the military front, then he was to be immediately decapitated under militarized adjudication; but, if soldiers, civilians, genyi or traders in the course of returning from battle-moving outward along the gradient-“"spread confusion," then they were still to be executed, but only after imperial approval. ${ }^{28}$

\section{The Association of the Frontier with Militarized Adjudication}

On January 19, 1696, in preparation for his third campaign against Zunghar leader Galdan, the Kangxi emperor (r. 1661-1722) issued a military order (junling) that articulated the physical frontier (bianjing) as the determinative factor in choosing between routine criminal adjudication and militarized adjudication. ${ }^{29}$ By doing this, the emperor affirmed the spatial application of militarized adjudication:

If any soldier deserts (tao) inside the frontier (bianjing yinei), then he will be adjudicated according to the substatute (yi dingli zhizui). If he deserts once the military has passed outside the frontier (chubian er tao), the high official with jurisdiction over him will send soldiers out to vigorously apprehend him and punish him under militarized adjudication. If those appointed to apprehend him fail to do so, they will be punished harshly. ${ }^{30}$

Four years later, on December 14, 1728 (YZ 6/11/14), during the Yongzheng emperor's campaign against the Zunghars, Shaanxi Governor-General Yue Zhongqi memorialized requesting that a sentence of execution be drafted

28. QSL-YZ, 130: 688b-689a.

29. QHDSL, 581: 531r-532v; QSL-KX, 169: 836a-837a.

30. QHDSL, 581: 531r-532v. 
[presumably by the Board of Punishments] for a rebel. Yue Zhongqi explained that because the rebel had been escorted to the inner empire, Yue was unable to simply execute him under militarized adjudication authority:

The rebel advocated for leading troops in rebellion. He is a really evil person. His misconduct cannot be wantonly tolerated. I have already sent him to Xi' an. The provincial judge already reviewed his case. Because he has already been brought to the interior, according to my review [of the regulations], he cannot be executed without going through the process of requesting an edict for decision. I do not dare to exercise my own convenience; therefore, I respectfully request an edict. ${ }^{31}$

Similarly, the frontier was again cited as the line of demarcation for militarized adjudication in the February 26, 1732 (YZ 12/3) case of Green Standard firsttime deserter Liu Tianqi. ${ }^{32}$ A native of Yunnan Province, Liu had been recruited as a soldier (bingding), deployed to Gansu province, and assigned to Ganzhou as part of the forces garrisoning that prefecture. Such a garrison-defense assignment was situated within the inner zones, but perhaps not epicenter, of the military operations gradient. On October 26, 1732, he deserted the garrison and returned home to Yunnan. Four months later, he was apprehended in his native county. He was tried under the routine adjudicative process. The Board of Punishments cited the following rule:

If deserters [from the northwest army] are captured in Mongolia, they are to be tried in the deployed camp, but if captured in the interior (neidi), they are to be brought to Beijing and turned over to the Board of War which will then turn them over to the Board of Punishments. ${ }^{33}$

Unlike the earlier Kangxi-era rule, this rule did not focus on where the desertion occurred, but where the deserter was apprehended. It provided a hard and fast rule to the campaign commander: there was no authority to engage in militarized adjudication in the inner empire. The emperor approved the sentence (which was drafted precisely according to the routine desertion statute set forth in the then-current version of the Qing Code).${ }^{34}$ The case was

31. ZPZZ-NPM, 402000634.

32. XKTB-FHA, 02-01-02-2494-004.

33. XKTB-FHA, 02-01-02-2494-004.

34. By the mid-Qianlong case, this would have been a case of a summary provincial-level trial and execution with no imperial review. By 1774, a representative similar caseexcept that it noted the execution of not one but seven campaign deserters-entailed 


\section{E. John Gregory}

documented in a full-blown criminal memorial despite that it was a military desertion case.

On March 22, 1735 (YZ 13/2/28), the Yongzheng emperor again authorized execution pursuant to militarized adjudication for soldiers and servants (genyi) stationed in the outer frontier (guanbing zhuzha waibian) who stole horses from Mongols. According to the edict to the Board of War:

The original justification for stationing official soldiers in the outer frontier was to defend the Mongols. If [soldiers stationed on the frontier] steal the Mongols' horses, that is turning defense into harassment. It should be punished more harshly in order to create a better deterrent. From now on, when official soldiers and their genyi as well as others steal Mongols' horses, they should be immediately tried to ensure matters are certain and then immediately executed on the spot. Have the appropriate high officials make this edict known widely. If Mongols steal the horses of official soldiers, or official soldiers steal one another's horses, then the cases shall be decided according to the old substatute. ${ }^{35}$

These cases all suggest to some degree the use of a frontier as a trigger for determining whether militarized adjudication should apply in a given case. They go further than the earlier cases that were directly associated with military activity and show that the physical frontier itself, likely because of its broad association with potential military activity and security from outside invasion, could and did serve the legal function of distinguishing modes of adjudication.

\section{Expanding Imperial Space, the Imperial Standard, and the Imperial Will}

Fairly rare prior to the Qianlong era, militarized adjudication expanded rapidly during that emperor's reign. As Zhang Shiming has argued in greater detail, understanding militarized adjudication spatially makes sense because imperial space itself expanded rapidly through the application of military force during this period. ${ }^{36}$ While the term "yi junfa congshi" does continue to appear in the record during this time, references to the "imperial standard" (literally, "standard with the king's command," wangming qipai; M: hesei

no central government review, immediate execution, and was documented in a palace memorial (zhupi zouzhe) only seven folds in length. ZPZZ-NPM, 403027684.

35. QSL-YZ, 152: 876a-876b.

36. Zhang 2012: 571. 
kiru temgetu) came to constitute a far more common marker of militarized adjudication during the Qianlong reign. True to its name, the Qing version of this standard was emblazoned with both the Chinese character "order" (ling) and the Manchu word "law" (fafun), suggesting the dual military-legal basis of militarized adjudication and reflecting the emperor's authority. ${ }^{37}$
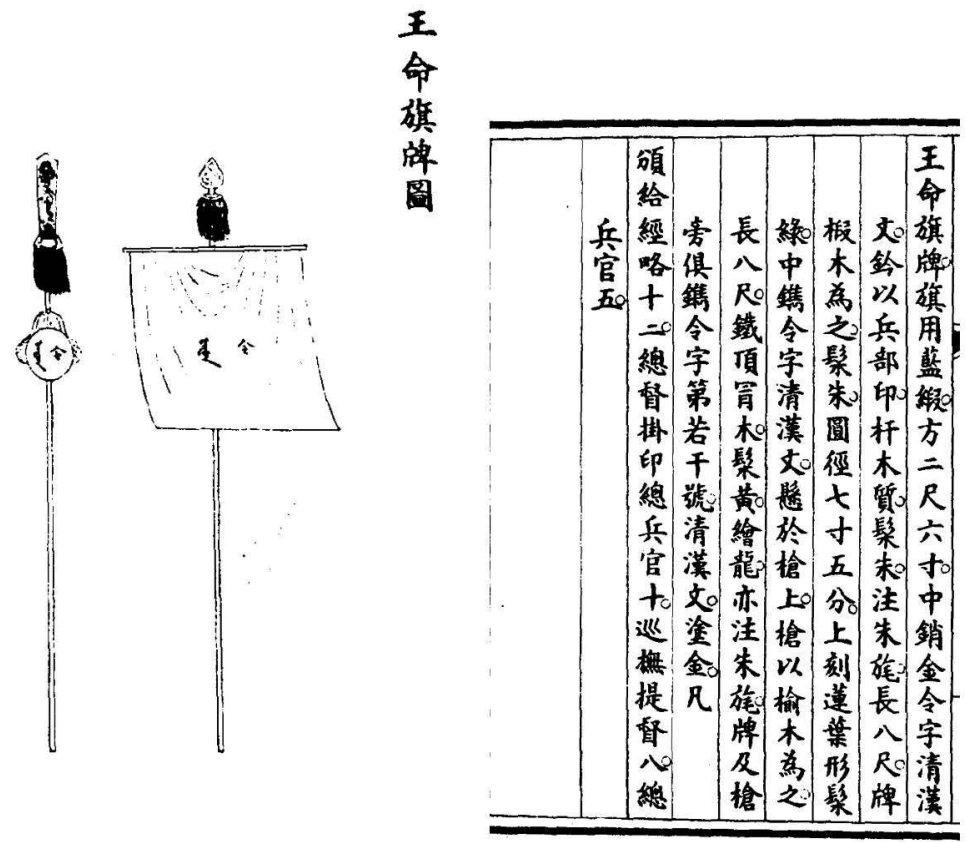

\section{Imperial standard from the Qing Collected Statutes}

The imperial standard is easily traceable to the Ming Dynasty and early Qing, although it did not become the primary discursive marker of militarized adjudication in the documentary record until the Qianlong reign. Wang Yangming referred to the standard as the military commander's symbol of militarized-adjudication authority. ${ }^{38}$ In 1647 Shaanxi governor Lei Xing noted that it was then currently a time of active military operations (zhengzai yongjun zhi ji), and that without an imperial standard, any exercise of junfa would not

37. QHD-Illustrations (1899), 106: 38r-38v.

38. Wang 2011: 32: 40v. 


\section{E. John Gregory}

be legitimate. "39 In 1724, the Yongzheng emperor noted that the standard was to be maintained by each governor-general, governor, provincial military commander, and regional commander. ${ }^{40}$ According to the 1764 Collected Statutes, imperial standards were issued to all specially-appointed supreme commanders as well as governors, governors-general, provincial military commanders and regional commanders (and that if they damaged or lost them, they would be punished). ${ }^{41}$ Still, prior to the Qianlong reign individual cases of militarized adjudication invoking the imperial standard are very rare in the archives. It was nowhere referenced in the Qing Code until 1789, although it was becoming prominent in the adjudicative discourse since at least 1761 .

The increase of militarized adjudication during the Qianlong era seems to be related to that particular emperor's use of military force. The Qianlong emperor fashioned himself the "Old Man of the Ten Great Victories (shiquan laoren)," many of which were actually frontier debacles, and the worst of which was his far off southern Burma campaign(s) (1765-1770). ${ }^{42}$ It was during the Burma debacle that cases of militarized adjudication "under the imperial standard" became ubiquitous, especially in cases of campaign dissertation. ${ }^{43}$ Cases processed under militarized adjudication became so common during this campaign that the language used in the memorial notifying the emperor of an execution was standardized:

According to the substatute, when soldiers desert from a military campaign, their punishment will be drafted as immediately decapitated (lijue), and governors and governors-general will rigorously apprehend them and execute them in the same place. At this time, I have apprehended [name of deserter] who deserted without authorization from the [name of the deployed camp]. It is a grave disregard for the law. I have therefore obeyed precedent by invoking the imperial standard and appointing officials who have executed [name of offender] at the execution grounds.

39. NGDK, 007193-001.

40. QSL-YZ, 33: 501a-501b; NGDK, 011686-001; there are additional Qing-era examples as well, such as NGDK, 007193-001 and QSL-QL, 83: 316a.

41. QHD (1753), 73: 6v.

42. Waley-Cohen 2006 and 2009: 45.

43. For instance, see ZPZZ-FHA, 04-01-26-004-066 / 04-01-26-001-1822; ZPZZ-FHA, 04-01-01-0279-006 / 04-01-01-038-2187; ZPZZ-FHA, 04-01-12-0128-103 / 04-0112-022-1464; ZPZZ-FHA, 04-01-01-0323-022 / 04-01-01-043-1557; ZPZZ-FHA, 04-01-16-0057-062 / 04-01-16-009-0161; ZPZZ-FHA, 04-01-01-0323-021 / 04-0101-043-1551; ZPZZ-FHA, 04-01-01-0279-009 / 04-01-01-038-2201. 
Once formulated, this language became standard in almost all desertion summary executions throughout the rest of the Burma campaign and the rest of the Qianlong reign, including in all his remaining "Great Campaigns." ${ }^{44}$ These very brief - usually no more than six or seven folds - memorials were mere notices to the emperor that an execution had taken place. Interestingly, the language of "imperial standard" began to fade (but never disappeared) from the historical record right about the time that the term jiudi zhengfa (another term for summary execution) began to increase in frequency during the Daoguang reign (1821-1850).

\section{Conclusion}

During times of peace, cases arising out of the institutional military and in the civilian context were mostly tried according to a routine process that involved multiple levels of hierarchical review; moreover, cases involving the taking of a life or death penalty cases, were, in general, supposed to be reviewed by the emperor. Militarized adjudication, however, reflected simplified procedures that sometimes did not even require pre-execution notice to the emperor, let alone by-case imperial authorization. Through at least the end of the Yongzheng era, the use of militarized adjudication closely corresponded with the proximity of the crime to actual military operations, a concept I explain using the idea of a "gradient of military of operations." Over time, the frontier - which itself signified a greater proximity to military operations-also came to represent a line of legal demarcation for the use of militarized adjudication. In some sense, the frontier itself provided an alternative spatial condition that could supplement or even substitute for kinetic military operations as a precondition of militarized adjudication, a sort of constructive military operation imprinted on physical space. Under certain circumstances and for certain types of crimes, militarized adjudication was appropriate on the frontier, but not in the inner empire. There was a marked increase in the use of militarized adjudication during the Qianlong era that corresponded with the more robust use of the military on the frontiers which in turn corresponded with the expansion of imperial space. This also reflected a spatial application of militarized adjudication. Tracking the spread of the symbolic and linguistic markers of militarized adjudication, such as the sharp

44. This language is quoted from a memorial by Liangking, ZPZZ-NPM,403024416. More examples from the Burma campaign include ZPZZ-NPM, 403025022, 403024924, 025073, 025386, 025393, 025686, 026169, 026278, 201870, 026710, 10935, 027684. 


\section{E. John Gregory}

rise in occurrences of the term "execution under the imperial standard" during the Qianlong era, helps us to understand changes in eighteenth century law, as exemplified by the spread of militarized adjudication, and more generally the legalization of space in late imperial China.

\section{DATing Conventions}

CZ. Chongzhen period (1627-1644)

SZ. Shunzhi period (1643-1661)

KX. Kanxi period (1661-1722)

YZ. Yongzheng period (1722-1735)

QL. Qianlong period (1735-1796)

\section{BIBLIOGRAPHY}

\section{List of abbreviations for primary sources}

NGDK. Zhongyang yanjiuyuan lishi yuyan yanjiusuo xiancun Qingdai Neige daku yuancang Ming-Qing dang'an 中央研究院歷史語言研究所現存清代内閣大庫 原藏明清檔案 (Ming-Qing Documents from the Qing Dynasty Grand Secretariat Archive in the Possession of the Institute of History and Philology, Academia Sinica). Taipei. Academia Sinica. Each case is identified by serial number.

QHD (1753). QL 29 (1753) version of the Qing Huidian. Electronic version of Siku Quanshu.

QHD (1899). Qing huidian (Collected Statutes of the Qing), 1899 edition.

QHDSL.Daqing huidian shili 大清會典事例 (The Collected Institutes and Precedents of the Great Qing). 1991 (1899). Beijing: Zhonghua Shuju.

QHDZL.Qinding daqing huidian zeli 欽定大清會典則例 (Qing Collected Regulations) [started in 1747 and completed in 1764]. Electronic version of Siku Quanshu.

QSL. Veritable Records of the Qing Dynasty (Qing shilu 清實錄), Shunzhi Reign (SZ), Kangxi Reign (KX), Yongzheng Reign (YZ), Qianlong Reign (QL). (Beijing: Zhonghua Shuju 中華書局, 1985).

XKTB-FHA. Board of Punishment [Technically the Office of Scrutiny for the Board of Punishment] Routine Criminal Memorial (Xingke tiben 刑科題本). First Historical Archives, Beijing.

XKTB-NGDK. Board of Punishment [Technically the Office of Scrutiny for the Board of Punishment] Routine Criminal Memorial (Xingke tiben). Great Secretariat Archives located at the Fusinian Library, Institute of History and Philology, Academia Sinica, Taiwan.

ZPZZ-FHA. Palace Memorials Archive (zhupi zouzhe). Held at the First Historical Archives, Beijing. Identified by serial number. 
ZPZZ-NPM. Palace Memorials Archive (zhupi zouzhe). Held at the National Palace Museum, Taipei. Identified by serial number.

\section{Other published sources}

BodDE, Derk and Morris, Clarence (1973). Law in Imperial China: Exemplified by 190 Ch'ing Dynasty Cases. Philadelphia: University of Pennsylvania.

CHANG, Wejen 張偉仁 (1994). “Legal Education in Ch'ing China.” In Education and Society in Late Imperial China, 1600-1900, edited by Benjamin A. ELMAN and Alexander WoODSIDE. Berkeley: University of California Press.

FARQuHAR, David M. (1968). "Origins of the Manchu's Mongolian Policy." In The Chinese World Order, edited by John K. FAIRBANK. Cambridge: Harvard University Press.

GrEGORY, E. John (2015). "Desertion and the Militarization of Qing Legal Culture," $\mathrm{Ph} . \mathrm{D}$. diss. Georgetown University. https://repository.library.georgetown.edu/ handle/10822/761498.

GuY, R. Kent (2010). Qing Governors and Their Provinces: The Evolution of Territorial Administration in China, 1644-1796. Seattle: University of Washington Press.

Heuschert, Dorothea (1998). "Legal Pluralism in the Qing Empire: Manchu Legislation for the Mongols." The International History Review 20.2: 310-24.

Jones, William C. (1994) The Great Qing Code. New York: Oxford/Clarendon Press.

LONG, Fenglan 龍鳳蘭 (2014). “'Xingfa shiqing shizhong' yanjiu ‘刑法世輕世重”研 究 (Research into the concept of adjusting the severity of criminal law based on the times)." Fazhi yu shehui, 1: 291-292.

QI, Jiguang 戚繼光 (2012 [1560]). Jixiao xinshu 紀效新書 (A New Treatise on Disciplined Service). Annotated by ZHANG Haipeng 張海鵬. Taipei: Wuzhou Press.

SAWYER, Ralph D. (1993). The Seven Military Classics of Ancient China. Boulder: Basic Books.

WAKEMAN, Frederick (1985). The Great Enterprise: The Manchu Reconstruction of Imperial Order in Seventeenth-Century China. Berkeley: University of California.

WALEY-COHEN, Joanna (2009). "Militarization of Culture in Eighteenth Century China." In Military Culture in Imperial China, edited by Nicola DI Cosmo. Cambridge: Harvard University Press.

WALEY-COHEN, Joanna (2006). The Culture of War in China: Empire and the Military under the Qing Dynasty. London: I.B. Tauris.

WANG, Shouren 王守仁 (2011). Wang Yangming quanji 王陽明全集 (Complete Works of Wang Yangming). Shanghai: Shanghai guji chubanshe.

ZHANG Shiming 張世明 (2012). Sifa changyu 司法場域 (The Judicial Field), vol. 4 of Falü, ziyuan, yu shikong jiangou: 1644-1945 de Zhongguo 法律、資源與時空建 構: 1644-1945 年的中國 (Law, Resources, and Time-Space Constructing China in 1644-1945). Guangzhou: Guangdong renmin chubanshi.

ZHAO Xianhai 趙現海 (2012). Mingdai jiubian changcheng junzhenshi 明代九邊長城 軍鎮史 (The history of the junzhen along the Great Wall and Nine Frontier region during the Ming Dynasty). Beijing: Social Sciences Academy Press. 


\section{E. John Gregory}

Zhongshu Zhengkao 中樞政考 (1742), available at the National Palace Museum Documents Library, Taipei, Taiwan.

ZHOU, Jian 周健 (2008). Zhongguo junshifa shi 中國軍事法史 (The history of Chinese military law), vol.1 of Jun shi fa wen ji 軍事法文集 (An anthology of military law). Beijing: Falü chubanshe.

ZHOU, Jian 周健 and Jia Guowen 賈國文 (1999). “Zhongguo gudai junfa de zaoqi xingtai 中國古代軍法的早期形態.” Journal of the Xi'an Political Institute 12:2.

ZHU, Xiaohong 朱曉紅 (2010). “Lun 'Xing shiyu bing er zhongyu li' jian lun Zhongguo junshifa de qi yuan 論’刑始於兵而終於禮”兼論中國軍事法的起源 (A discussion of 'Punishment started with the military and ended with rights' and a discussion of the origins of Chinese military law)." Journal of Xi'an Political Institute 23.2.

ZENG, Xianyi 曾憲義 et al. (eds.) (2011). Zhongguo chuantong falü wenhua yanjiu 中 國傳統法律文化研究 (Research into Traditional Chinese Legal Culture). Vol.2, Zui yu fa 罪與罰 (Crime and Punishment). Beijing: Zhongguo Renmin daxue chubanshe.

\section{GLOSSARY}

bianjing yinei 邊境以内

bianjing 邊境

bianyi xingshi 便宜行事

Bingbu Chufen Zeli 兵部處分則例

bingding 兵丁

Binglü 兵律

chubian er tao 出邊而逃

chujue panjun 處決叛軍

Daqing luli 大清律例

duizhang 隊長

faling 法令

fuyue 斧銊

Ganzhou 甘州

genyi 跟役

gongqing wangming jixing zhengfa 恭請王命即行正法

guanbing zhuzha waibian 官兵駐笭外邊

haoling 號令

jiazhang 甲長

jingliie 經略

jiudi zhengfa 就地正法

Jixiao xinshu 紀效新書 
Military Operations, Law and Late Imperial Space

ju zhi junfa 俱治軍法

junfa 軍法

junji 軍紀

junling 軍令

junying 軍營

Lei Xing 雷興

ling 令

Liu Tianqi 劉天奇

lizheng junfa 立正軍法

neidi 内地

Qi Jiguang 戚繼光

qie 怯

qinchai dachen 欽差大臣

shangfa 賞罰

shangfang baojian 尚方寶劍

shiqing shizhong 世輕世重

shiqing shizhong' yanjiu '刑法世輕世重

shiquan laoren 十全老人

tao 逃

teban suxing jieqiu zhi fa 特頒速刑節求之法

toumu 頭目

wangming qipai 王命旗牌

xianzhan houzou 先斬後奏

xing shiyu bing 刑始於兵

xingke tiben 刑科題本

xun 汛

yi dingli zhizui 依定例治罪

yi junfa congshi 以軍法從事

Yue Zhongqi 岳鍾琪

zeiyi 賊夷

Zhang Jinyan 張經彥

zhengzai yongjun zhi ji 正在用軍之際

Zhongshu zhengkao 中樞政考

zhupi zouzhe 硃批奏摺

zixin 自新

Zizhi tongjian 資治通鑑

zongtong guan 總統官

$z u i$ 罪 
